\title{
Kinerja Pemerintah DKI Jakarta Dalam Kerjasama Sister City Dengan Seoul di Bidang Perdagangan
}

\author{
Atika Dian Anggraini ${ }^{1}$
}

\begin{abstract}
International cooperation nowadays is not only designated for goverment to government relations, but also for substate and non-state actors as each has equal opportunities to involve in international relations. The province of Jakarta as one of the sub-state actors implements this opportunity by establishing sister city cooperation with local governments of similar interests from around the world. The main focus in this paper is to evaluate the effectiveness of the sister city between the province of Jakarta and Seoul, especially in trade sector, including to find the impediments in its implementation.
\end{abstract}

Keywords: sister city, trade, cooperation, evaluation.

\begin{abstract}
Abstrak
Kerjasama internasional yang dilakukan saat ini tidak lagi hanya diperuntukan untuk hubungan yang dilakukan oleh pemerintah antar negara saja, karena aktor lokal maupun aktor non-negara saat ini juga mempunyai kesempatan yang sama untuk terlibat dalam hubungan internasional. Pemerintah DKI Jakarta sebagai salah satu aktor lapisan di bawah Pemerintah Indonesia mengimplementasikan kesempatan tersebut dengan menjalin kerjasama sister city antar pemerintah daerah dari berbagai negara. Titik fokus pembahasan tulisan ini adalah mengevaluasi kinerja Pemerintah DKI Jakarta dalam kerjasama sister city dengan Seoul, termasuk melihat faktor-faktor yang menghambat implementasi kerjasama.
\end{abstract}

Kata Kunci: sister city, perdagangan, kerjasama, evaluasi.

\section{Pendahuluan}

Jakarta merupakan sebuah kota yang memiliki kedudukan strategis baik karena statusnya sebagai ibukota negara Indonesia maupun sebagai kota yang menjadi pusat dari berbagai aktivitas nasional, baik itu pemerintahan, politik maupun ekonomi. Dengan kondisi tersebut, selain membuat Kota Jakarta menjadi pusat tolak ukur dalam berbagai bidang bagi kota-kota lainnya dalam konteks nasional, juga membuat Jakarta menjadi perhatian bagi banyak pihak hingga tingkat internasional. Terlebih, dengan segala potensi dan kemajuan yang dimiliki Kota Jakarta, kemudian membuat tercatatnya Jakarta sebagai kota di Indonesia yang paling diminati untuk menjadi mitra oleh berbagai pemerintah kota di dunia dalam kerjasama sister city (Navisah, 2016). Kondisi tersebut juga membuat tidak hanya pemerintah negara berkembang yang berlomba-lomba melakukan kerjasama dengan Pemerintah DKI Jakarta, tetapi pemerintah daerah negara maju juga tertarik untuk melakukan kerjasama dengan Kota Jakarta, seperti Pemerintah Kota Seoul,

\footnotetext{
${ }^{1}$ Peneliti di Laboratorium Diplomasi, Jurusan Hubungan Internasional UPN "Veteran" Yogyakarta. Jl. Babarsari 2, Tambakbayan, Yogyakarta. E-mail: tikagraini@ymail.com
} 
Korea Selatan.

Kerjasama sister city antara DKI Jakarta dengan Seoul telah dirintis sejak tahun 1984 dibawah kuasa Gubernur I.R Soeprapto yang menjadi salah satu kerjasama tertua yang dapat dilakukan oleh pemerintah daerah di Indonesia. Terwujudnya kerjasama sister city antara DKI Jakarta dengan Seoul merupakan cerminan dari berkembangnya teori paradiplomasi yang menekankan pada dilakukannya hubungan luar negeri oleh entitas sub state dalam rangka mengejar suatu kepentingan bersama (Mukti, 2013: 2). Kepentingan bersama antara DKI Jakarta dan Seoul muncul dari banyaknya persamaan yang dimiliki. Salah satu persamaan yang dimiliki ialah kedua kota sama-sama berkedudukan sebagai ibukota negara dimana kondisi tersebut kemudian memberikan dampak lain berupa paling pesatnya perkembangan ekonomi yang dialami baik oleh Kota Jakarta maupun Kota Seoul apabila dibandingkan diantara kota-kota lainnya di negara masing-masing. Meskipun begitu, baik DKI Jakarta maupun Seoul menyadari akan keterbatasan kemampuan yang dimiliki untuk memenuhi kebutuhan masyarakatnya secara sendiri, sehingga membutuhkan mitra untuk saling melengkapi dan saling memberikan keuntungan satu sama lain. Langkah yang dilakukan untuk saling melengkapi dan saling memberikan keuntungan tersebut dilakukan melalui kesepakatan kerjasama di bidang perdagangan dalam konteks sister city.

Upaya sebuah kerjasama yang dilakukan oleh setiap aktor selain harus direncanakan dengan matang pada awal pembentukannya, juga penting untuk melakukan evaluasi dalam suatu periode tertentu. Apabila sebuah kebijakan dipandang sebagai suatu pola kegiatan yang berurutan, maka sebenarnya letak evaluasi merupakan tahap akhir dalam proses kebijakan (Winarno, 2008: 225). Namun demikian, beberapa ahli lainnya memberikan pandangan sebaliknya bahwa evaluasi bukan hanya merupakan tahap akhir dari kebijakan yang dijalankan, melainkan evaluasi dipandang sebagai suatu kegiatan yang fungsional (Winarno, 2008, 225). Artinya, evaluasi mempunyai pengaruh pada pencapaian tujuantujuan lainnya karena evaluasi merupakan proses penilaian yang digunakan untuk menimbang manfaat atau efektivitas dari suatu kegiatan yang dilaksanakan. Kondisi tersebut kemudian membuat evaluasi sangat dibutuhkan selama proses kerjasama berlangsung sebagai input yang berguna untuk mengetahui bila terjadi penyimpangan atau kesalahan sehingga dalam pengambilan kebijakan yang akan datang dapat menghindari adanya pengulangan kesalahan yang sama dan dapat berjalan lebih baik lagi dari segi operasional maupun 
dari segi implementasinya. Dengan begitu, pokok permasalahan dalam penelitian ini ialah: "Bagaimana hasil evaluasi kinerja Pemerintah DKI Jakarta dalam kerjasama sister city dengan Seoul di bidang perdagangan?”.

\section{Metode}

Pembahasan atas pertanyaan di atas dilakukan dengan mengadopsi model evaluasi kerjasama sister city yang telah dilakukan oleh Puspitasari dan Hudalah (2013) dalam evaluasi yang dilakukannya mengenai kerjasama sister city kota Surabaya. Mereka mengembangkan tiga variabel utama dalam evaluasi kinerja kerjasama antar-kota, yakni variabel input, proses, dan output, dimana masing-masingnya dipecah ke dalam sejumlah indikator turunan. Penjelasan mengenai variabel dan indikator yang digunakan dapat dilihat dalam tabel berikut:

\begin{tabular}{|c|c|c|}
\hline No. & Variabel & Indikator \\
\hline 1 & Variabel input & $\begin{array}{l}\text { 1. Infrastruktur hukum yang mamayungi } \\
\text { kerjasama sister city } \\
\text { 2. sumber daya manusia dan sumber daya alam }\end{array}$ \\
\hline 2 & Variabel proses & $\begin{array}{l}\text { 1. Stabilitas dan kontinuitas program kerjasama } \\
\text { sister city yang berhasil diimplementasikan } \\
\text { 2. Keterlibatan masyarakat dalam mendukung } \\
\text { implementasi program }\end{array}$ \\
\hline 3 & Variabel output & $\begin{array}{l}\text { 1. tercapainya tujuan kerjasama sister city } \\
\text { 2. kontinuitas kerjasama, atau dibukanya } \\
\text { kerjasama baru }\end{array}$ \\
\hline
\end{tabular}


Selanjutnya, penerapan model evaluasi tersebut dilakukan secara kualitatif di mana data diperoleh melalui wawancara, pembacaan nota kerjasama serta laporan resmi dari lembaga pemerintah terkait, kemudian ditriangulasi dengan liputan berita di koran yang relevan. Interpretasi data dilakukan dengan memperhatikan sumber-sumber data yang telah dikoleksi dan dikategorisasi, kemudian dibandingkan dengan hasil penelitian sebelumnya.

\section{Pembahasan}

Kerjasama sister city merupakan kerjasama yang terjalin dengan melibatkan berbagai aspek mulai dari komponen masyarakat, sumber daya alam hingga meliputi berbagai bidang kerjasama. Selain kegunaan evaluasi yang telah disebutkan sebelumnya, evaluasi pada kerjasama sister city juga digunakan untuk melihat optimalisasi berbagai komponen yang terlibat dalam kerjasama sister city tersebut. Selain itu, evaluasi dalam penelitian ini juga dapat digunakan untuk melihat apakah kerjasama di bidang perdagangan mengalami peningkatan atau justru mengalami penurunan. Untuk mengetahui kesemua hal tersebut, maka dibutuhkan suatu penilaian kinerja yang tidak dapat didasarkan pada pendapat (opinion), melainkan harus didasarkan pada fakta (fact) dengan indikator yang jelas dan terukur (Yudoyono, 2001).
Berdasarkan penelitian Puspitasari dan Hudalah (2013), terdapat setidaknya tiga variabel yang dapat digunakan sebagai instrumen evaluasi minimal untuk menilai efektivitas kerjasama sister city yang dilakukan pemerintah daerah. Variabel input dimaksudkan untuk menilai ada/sesuai atau tidaknya landasan peraturan perundangundangan yang berlaku serta ketersediaan sumber daya yang akan menjadi potensi dilakukannya kerjasama sister city di berbagai bidang. Variabel proses dimaksudkan untuk mengetahui stabilitas atau kontuinitas program kerjasama yang telah direncanakan, serta partisipasi atau keterlibatan masyarakat sebagai stakeholder dalam proses kerjasama yang dilakukan. Variabel output dimaksudkan untuk menilai tercapainya tujuan yang sebelumnya telah disepakati dalam rencana kerjasama serta bagaimana kerjasama yang sudah terjalin dapat menjadi stimulus untuk melahirkan kerjasama-kerjasama baru.

Penerapan dari indikator penilaian kinerja tersebut terhadap kinerja Pemerintah DKI Jakarta dapat dijelaskan sebagai berikut:

\section{Indikator Input:}

1.1 Indikator mengenai kesesuaian landasan hukum yang digunakan oleh

Pemerintah DKI Jakarta dalam memulai kerjasama sister city dengan peraturan perundang-undangan yang berlaku. 
Sejalan dengan dijadikannya pemerintah daerah sebagai salah satu aktor dalam hubungan luar negeri, maka segala perjanjian kerjasama internasional yang dilakukan oleh pemerintah daerah haruslah mengacu pada panduan teknis serta aspek hukum yang berlaku untuk menghindari adanya tumpang tindih kekuasaan. Dari berbagai landasan hukum yang ditujukan sebagai pedoman bagi setiap pemerintah daerah di Indonesia dalam melakukan hubungan luar negeri, ditemukan satu landasan hukum yang penerapannya tidak dilakukan oleh Pemerintah DKI Jakarta sesuai dengan peraturan yang berlaku. Peraturan yang dimaksud yakni Permendagri No.3 tahun 2008 tentang Pedoman Pelaksanaan Kerjasama Pemerintah Daerah dengan Pihak Luar Negeri yang mengatur mengenai isi yang harus dimuat pada kesepakatan kerjasama menjadi satu-satunya pasal yang penerapannya tidak sesuai dengan pedoman yang dimaksud.

Kesepakatan kerjasama sister city antara DKI Jakarta dan Seoul yang tertuang dalam Joint Communique hanya memuat pernyataan secara singkat bahwa telah terjadi sebuah kesepahaman antara kedua belah pihak untuk melakukan kerjasama dalam konteks sister city, dimana seharusnya apabila mengacu kembali pada Permendagri No.3 tahun 2008 maka isi kesepakatan kerjasama haruslah memuat konten seperti: obyek kerjasama, hak dan kewajiban, kedudukan para pihak, tanggung jawab serta penyelesaian sengketa pihak yang bekerja sama. Perbedaan penerapan dengan peraturan yang berlaku tersebut dapat digolongkan sebagai bentuk penyimpangan yang harus segera diperbaiki. Meskipun memang Pemerintah DKI Jakarta telah melakukan penandatangan kerjasama jauh sebelum pedoman pelaksanaan kerjasama pemerintah daerah dengan pihak luar negeri dibuat, tetapi seharusnya Pemerintah DKI Jakarta dapat menyesuaikan kondisi perjanjian kerjasama tersebut setelah pedoman yang dimaksud disahkan berlaku. Penyimpangan tersebut sekaligus menjadi hambatan pertama yang ditemukan dalam penelitian ini.

1.2 Indikator ketersediaan sumber daya manusia serta sumber daya alam untuk mendukung dilakukannya kerjasama diberbagai bidang.

Syarat berjalannya suatu kerjasama adalah kepemilikan sumber daya 
(resources). Sumber daya yang dimaksud dan dibutuhkan dari sebuah kerjasama tersebut ialah sumber daya alam sebagai unsur work atau lingkup bidang yang akan dikerjasamakan serta sumber daya manusia sebagai unsur yang menjalankan kerjasama. Apabila dilihat dari unsur sumber daya manusia, Biro Kepala Daerah dan Kerjasama Luar Negeri (Biro KDH\&KLN) sebagai biro yang menangani hubungan luar negeri sekaligus implementor dalam kerjasama sister city di pihak Pemerintah DKI Jakarta, ditemukan data bahwa sumber daya manusia yang dalam hal ini ialah pegawai yang berada dalam Biro KDH\&KLN tersebut telah memumpuni baik dari segi kuantitasnya maupun kualitasnya. Selain adanya kualifikasi pendidikan bagi setiap jenjang jabatan yang ada di Biro KDH\&KLN, diklat prajabatan sebagai basic training yang harus dilalui sebelum pengangkatan sebagai pegawai serta adanya kualifikasi berbagai kemampuan (skill) pendukung seperti kemampuan berbahasa asing, penguasaan teknik diplomasi dan negosiasi kemudian membuat sumber daya manusia di Biro KDH\&KLN dapat dikatakan mempunyai kapabilitas yang cukup untuk menangani kerjasama dengan pihak asing. Dalam hal ini, faktor kelemahan birokrasi yang sering menjadi alasan suatu kerjasama luar negeri tidak dapat berjalan efektif dapat dihindari akibat adanya sumber daya manusia yang mempunyai kapabilitas dan kompeten dibidangnya. Namun begitu, untuk semakin meningkatkan keprofesionalitasan pegawai yang sangat berpengaruh tehadap semakin baiknya kinerja pegawai di Biro KDH\&KLN, maka seharusnya diimbangi dengan berbagai diklat lanjutan yang terdiri dari diklat kepemimpinan, diklat fungsional dan diklat teknis. Kesemua diklat tersebut dibutuhkan untuk meningkatkan kapabilitas pegawai itu sendiri baik dari segi pengetahuan, keahlian, mutu maupun keterampilan. Namun, dalam penelitian ini ditemukan hambatan yang kedua yakni kesemua informasi mengenai diklat lanjutan tersebut serta informasi terkait capaian kerjasama yang telah dilakukan oleh pegawai di Biro KDH\&KLN selama melakukan kerjasama sister city tidak dapat diperoleh dari berbagai sumber atau masih minim ketersediaanya, sehingga kemudian berdampak pada sulitnya masyarakat untuk mengetahui serta mengawasi jalannya kerjasama sister city dengan Seoul.

Sedangkan apabila dilihat dari 
sumber daya alamnya, Jakarta merupakan sebuah kota yang mempunyai lahan daratan serta lautan yang kemudian menjadikan Jakarta memiliki kekayaan sumber daya alam baik mineral, agrikultur maupun lautan. Hal tersebut secara otomatis membuat unsur ketersediaan sumber daya alam terpenuhi oleh Jakarta. Kondisi tersebut kemudian dimanfaatkan oleh Pemerintah DKI Jakarta untuk menjalin kerjasama di bidang perdagangan dengan berbagai pihak dalam rangka mendapatkan keuntungan yang dapat digunakan untuk berbagai kebutuhan pembangunan di Jakarta sendiri. Salah satu mitra Kota Jakarta dalam kerjasama perdagangan adalah Kota Seoul, dimana Kota Seoul juga diketahui sebagai kota yang memiliki kekurangan akan sumber daya alam karena faktor geografis negaranya yang kurang menguntungkan. Terbukti, Kota Seoul memiliki permintaan terhadap komoditi tertentu yang dihasilkan di Jakarta yang dapat diklasifikasi menjadi dua jenis sektor, yakni sektor agrikultur dan sektor industri pengolahan (manufactured). Sektor agrikultur yang dimaksud mencakup komoditi rempah-rempah, makanan beku hasil laut dan sayuran, gum, keripik kentang, dan tanaman hias, sedangkan dari sektor industri manufaktur mencakup produk plastik, furnitur, barang dari kulit, produk batu yang termasuk dalam jenis barang galian bukan logam, dan bahan kimia dan barang-barang dari kimia (Kemendag RI, n.d.). Kondisi tersebut kemudian membuat Jakarta terus melakukan ekspor atas permintaan komoditi dari Seoul tersebut setiap tahunnya, dan kegiatan ekspor merupakan salah satu unit yang menyumbang pendapatan suatu daerah melalui penerimaan pajak. Dengan begitu, ketersediaan sumber daya alam di Jakarta sangat berperan penting dalam membantu peningkatan pendapatan daerah Jakarta itu sendiri.

\section{Indikator Proses}

2.1 Indikator stabilitas atau kontuinitas Pemerintah DKI Jakarta dalam melaksanakan kerjasama sister city dengan Seoul.

Salah satu variabel penting agar kerjasama sister city yang terjalin dapat terus berjalan ialah terdapatnya komunikasi yang aktif dan rutin sehingga hubungan kerjasama dapat terus dipantau bahkan ditingkatkan. Kerjasama sister city antara DKI Jakarta dengan Seoul apabila dihitung hingga tahun 2015 maka kerjasama tersebut telah berusia 31 
tahun. Dapat berlangsungnya kerjasama dari dua kota yang berbeda negara, berbeda bahasa serta berbeda budaya tersebut tidak lain disebabkan karena faktor komunikasi dan koordinasi yang baik yang dijalin oleh kedua pemerintah kota. Komunikasi yang terjalin dengan baik ini dilandasi karena masing-masing pemerintah kota mempunyai lembaga khusus yang menangani kerjasama internasional dalam level antar kota, dimana DKI Jakarta memiliki Biro KDH\&KLN sedangkan Seoul memiliki institusi pengelola kerjasama sister citynya ialah International Affairs Division.

Selain itu, kontuinitas kerjasama kedua kota juga didukung karena faktor adanya dukungan dari pemerintah pusat yang dalam hal ini ialah Kementerian Luar Negeri berupa pendirian kantor kedutaan besar masing-masing negara (Indonesia dan Korea Selatan) yang berkedudukan tepat di kedua kota yang bermitra. Dengan berdirinya kantor kedutaan besar tersebut maka akan ditempatkan perwakilan-perwakilan resmi dari masing-masing negara yang memiliki fungsi dan kapabilitas khusus yang berhubungan dengan kerjasama internasional baik yang ditingkat pemerintah pusat maupun pemerintah daerah, sehingga kehadiran perwakilan tersebut sangat signifikan guna mendukung pelaksanaan hubungan luar negeri antara masing-masing kota.

Faktor lain yang juga turut berkontribusi besar sehingga kerjasama sister city DKI Jakarta dengan Seoul dapat terus berjalan ialah karena masingmasing pemimpin kota sangat mendukung berjalannya kerjasama sister city yang dilakukan yang dibuktikan dengan terus terjadi kunjungan rutin secara bergantian selama tahun 20112015. Dari kunjungan tersebut kemudian terjadi berbagai kegiatan diskusi, studi banding hingga melakukan pertukaran tenaga ahli yang dimana hal tersebut semakin memperkuat kerjasama yang dilakukan.

2.2 Indikator keikutsertaan masyarakat sebagai stakeholder dalam kerjasama sister city yang dilakukan.

Ide kerjasama sister city pada awalnya ialah untuk peningkatan people to people diplomacy, namun seiring dengan perkembangan zaman, tujuan tersebut bergeser untuk mewujudkan sebuah kerjasama yang lebih konkrit yakni saling menguntungkan kedua belah pihak dengan tidak melupakan peran serta masyarakat didalamnya. Di pihak 
Pemerintah DKI Jakarta sendiri, masyarakat yang terlibat dalam sister city DKI Jakarta dengan Seoul telah mewakili sejumlah komponen dalam masyarakat, yakni pegawai, pemuda, pelajar dan pelaku dunia usaha. Kerjasama di bidang perdagangan yang dilakukan tentunya melibatnya pelaku dunia usaha yang dalam hal ini adalah perusahaan di dalamnya. Sebagaimana yang telah dijelaskan sebelumnya, pengiriman ekspor terhadap komoditi tertentu dari Jakarta ke Seoul yang dilakukan selama ini dilakukan oleh perusahaanperusahaan asal Jakarta yang kemudian perusahaan-perusahaan tersebut disebut sebagai potential supplier dalam perdagangan internasional. Namun, tidak hanya perusahaan sebagai pelaku dunia yang terlibat, komponen masyarakat lainnya yang terlibat seperti pemuda, pelajar dan pegawai masing-masing terlibat dalam bidang kerjasama yang berbeda. Pemuda Jakarta dalam hal ini yang tergabung dalam kelompok Jakarta Sister City Youth Program terlibat dalam kerjasama di bidang seni budaya, dimana kehadiran pemuda selain ditujukan untuk memperkenalkan kesenian dan kebudayaan yang dimiliki Jakarta melalui berbagai acara pertunjukkan di kota mitra, juga dimanfaatkan sebagai wadah pertemuan antara pemuda dari berbagai mitra sister city Jakarta untuk bersamasama membahas isu yang sedang berkembang dan mendiskusikannya bersama untuk dijadikan masukan bagi pemerintah kota tersebut. Keterlibatan stakeholder lainnya yakni pegawai dan pelajar merupakan stakeholder yang terlibat dalam kerjasama di bidang ketenagakerjaan, dimana kerjasama di bidang ini ditujukan untuk mendongkrak angka tenaga kerja aktif di DKI Jakarta melalui pemberian beasiswa untuk melanjutkan pendidikan pasca sarjana di Seoul dalam bidang administrasi publik bagi pegawai di Biro KDH\&KLN hingga pemberian pelatihan keterampilan bagi pelajar SMK atau vocational student di berbagai bidang seperti bidang otomotif, web program, web master, jewelry design, interior design, cooking dan cosmetic.

Secara keseluruhan, terlihat bahwa keterlibatan masyarakat Jakarta sebagai stakeholder dalam kerjasama sister city DKI Jakarta dan Seoul cukuplah tinggi. Keterlibatan stakeholder tersebut dapat dijadikan suatu bentuk kepedulian terhadap pembangunan dan kemajuan kota yang lebih baik. Selain itu, 
keterlibatan stakeholder dalam programprogram yang dibuat pemerintah kota dalam hal ini Pemerintah DKI Jakarta kemudian menjadi sebuah kontribusi besar yang dapat membantu dalam pencapaian tujuan peningkatan hubungan people to people diplomacy kedua kota.

\section{Indikator Output.}

3.1 Indikator tercapainya tujuan yang disepakati dalam kerjasama bidang perdagangan.

Ketersediaan sumber daya alam baik mineral, agrikultur dan lautan di Jakarta membawa Jakarta menjadi potential supplier bagi kebutuhan di Seoul. Dari data perdagangan yang diperoleh, komoditi yang diekspor setiap tahunnya ke Seoul yang terbagi menjadi dua jenis yakni produk bahan baku berbasiskan sumber daya alam dan juga produk hasil industri manufaktur terus mengalami peningkatan nilai realisasi ekspor, yakni pada tahun 2011 hanya mencapai nilai Rp. 24.232.202.714 kemudian mengalami peningkatan signifikan di tahun 2015 yang berhasil mencapai Rp. 69.714.695.364. ${ }^{2}$ Dengan terus meningkatnya nilai ekspor Jakarta ke Seoul tersebut kemudian berkontribusi besar terhadap peningkatan pendapatan DKI Jakarta pula. Terbukti, PAD Kota Jakarta di tahun 2011 yang hanya berjumlah Rp. 16.280.13 trilliun rupiah meningkat menjadi Rp. 40.355.85 trilliun rupiah di tahun 2015 (Badan Pengelolaan Keuangan dan Aset Daerah DKI Jakarta, 2015). Meningkatnya PAD Kota Jakarta tersebut kemudian mengindikasi bahwa kerjasama di bidang perdagangan yang dilakukan dengan Seoul membawa hasil positif, yakni mendorong pertumbuhan ekonomi yang salah satunya diwujudkan dengan meningkatnya pendapatan kota yang menjalin kerjasama.

3.2 Indikator terbukanya kerjasama baru di berbagai bidang.

Sebuah kerjasama yang dilakukan tidak hanya diharapkan dapat berjalan dengan lancar dan dinamis serta dapat mencapai hasil yang optimal, tetapi juga diharapkan dapat menjadi sebuah kerjasama pembuka bagi kerjasamakerjasama baru lainnya. Berdasarkan data yang diperoleh, sejauh ini kerjasama sister city antara DKI Jakarta dengan Seoul yang telah berlangsung selama tiga puluh satu tahun belum mampu men-

\footnotetext{
${ }^{2}$ Hasil wawancara melalui e-mail dengan Bpk. Hassan selaku staf Informasi dan Kepabeanan Bea Cukai, pada tanggal 9 Maret 2017.
} 
dorong pada penciptaan kerjasama baru di bidang-bidang lainnya antara kedua kota. Meskipun belum mampu mendorong terciptanya kerjasama di bidang baru lainnya dengan Seoul, namun dengan dijadikannya kerjasama sister city Jakarta dan Seoul sebagai salah satu dari enam kerjasama paling aktif dalam LKPJ Pemerintah DKI Jakarta kemudian memberikan dampak lain berupa banyaknya kota-kota lain di dunia yang ingin menjalin kerjasama sister city dengan DKI Jakarta. Hal tersebut dapat dilihat dengan terus dilaksanakannya penandatanganan dan kesepakatan kerjasama sister city oleh Pemerintah DKI Jakarta hingga tahun 2015.

\section{Kesimpulan}

Secara keseluruhan, pengukuran yang dilakukan untuk menilai kinerja kinerja Pemerintah DKI Jakarta dalam menjalani kerjasama sister city dengan Seoul menghasilkan hasil akhir kinerja Pemerintah DKI Jakarta yang cukup efektif. Diluar hambatan yang terjadi, penilaian kinerja Pemerintah DKI Jakarta yang dapat dikatakan cukup efektif tersebut beralasan karena kerjasama yang dijalin oleh DKI Jakarta dengan Seoul pada dasarnya telah memberikan manfaat, saling menguntungkan serta dapat mencapai tujuan yang diinginkan. Terlebih, dengan terlibatnya berbagai komponen masyarakat dalam kerjasama sister city yang dilakukan kemudian mengartikan bahwa program yang dibuat pemerintah tidak sebatas hanya dikelola dan dikendalikan oleh pemerintah saja, tetapi masyarakat dapat turut berpatisipasi bahkan dapat mengambil manfaat dari kerjasama sister city yang dilakukan Pemerintah DKI Jakarta tersebut. Selain itu, tercatatnya kerjasama sister city DKI Jakarta dengan Seoul sebagai salah satu dari enam sister city Kota DKI Jakarta yang sangat aktif merupakan pembuktian lain bahwa Pemerintah DKI Jakarta telah cukup baik dalam mengelola kerjasama sister city dengan Seoul. 


\section{Daftar Pustaka}

BPS DKI Jakarta, "Jakarta Dalam Angka 2016”, http://jakarta.bps.go.id/backend/pdf_publikasi/ Jakarta-Dalam-Angka-2016.pdf, diakses pada tanggal 10 Desember 2016.

BPS Provinsi DKI Jakarta, "Statistik Daerah Provinsi DKI Jakarta 2015”, http://jakarta.bps.go.id/ backend/pdf_publikasi/Statistik-Daerah-Provinsi-DKI-Jakarta-2015.pdf,_diakses pada tanggal 19 Januari 2017.

Badan Pengelolan Keuangan dan Aset Daerah, "LKPD 2015", http://bpkad.jakarta.go.id/filelampiran/LKPD-2015-AUDITED.pdf, diakses pada tanggal 25 Maret 2017

Mukti, Takdir Ali, Paradiplomacy Kerjasama Luar Negeri oleh Pemda di Indonesia, The Phinisi Press, Yogyakarta, 2013.

Kementerian Perdagangan "Finding Product \& Supplier", http://djpen.kemendag.go.id/ app frontend/imp profiles, diakses pada tanggal 15 Maret 2017.

Ikatan Jakarta Sister City, "Jakarta Sister City Program “ https://jakartasistercity.wordpress.com/ about/, diakses pada tanggal 8 Maret 2017.

Kementerian Luar Negeri Republik Indonesia, "Panduan Umum Tata Cara Hubungan dan Kerjasama Luar Negeri oleh Pemerintah Daerah Revisi Tahun 2006", http:// www.kemlu.go.id/Documents/Panduan\%20Umum\%20Tata\%20Cara\%20dan $\%$ 20Kerjasama\%20LN\%20oleh\%20Pemda/Panduan\%20Umum $\% 20$ Tata $\% 20$ Cara $\% 20$ dan $\%$ 20Kerjasama\%20LN\%20oleh\%20Pemda.pdf, diakses pada tanggal 10 Februari 2017.

Kementerian Perdagangan "Finding Product \& Supplier", http://djpen.kemendag.go.id/ app frontend/imp profiles, diakses pada tanggal 15 Maret 2017.

Navisah, Fitri, "Kerjasama Luar Negeri antara Pemerintah Kota Bandung dengan Kota Braunschweig Tahun 2000-2015”, http://repository.umy.ac.id/bitstream/ handle/123456789/7129/Jurnal.pdf?sequence $=9$ \&isAllowed $=\mathrm{y}$, diakses pada tanggal 5 Februari 2017.

Pemerintah Provinsi DKI Jakarta "Sumber Kekayaan Alam Jakarta”, http://www.jakarta.go.id/v2/ news/2008/01/Sumber-Kekayaan-Alam-Jakarta\#.WMtDvtJ97IU, diakses pada tanggal 16 Maret 2017.

Puspitasari, Gina, et. al, “Evaluasi Keberhasilan Kerjasama Antar Kota 'Sister City' Kota Surabaya”, Jurnal Perencanaan Wilayah dan Kota, vol. 2, no. 2, hal. 1-9.

Setda Provinsi DKI Jakarta, "LKPJ Gubernur Provinsi DKI Jakarta, Setda Provinsi DKI Jakarta", www.jakarta.go.id/.../2014-03-14_LKPJ_BAB_VI_KERJASAMA.pdf, diakses pada tanggal 8 April 2017.

Wawancara melalui e-mail dengan Bpk. Hassan selaku staf Informasi dan Kepabeanan Bea Cukai, pada tanggal 9 Maret 2017.

Winarno, Budi, Kebijakan Publik Teori dan Proses, PT Buku Kita, Jakarta, 2008, hal . 225.

Yudoyono, Bambang. (2001). Otonomi Daerah, Pustaka Sinar Harapan, Jakarta. 